\title{
EDITORIAL
}

\section{The OECD Model and Non-Member Countries}

\author{
J. David B. Oliver, Coopers \& Lybrand, London; Visiting Professor of International Taxation, London School of Economics
}

How is the OECD Model currently viewed by nonmember countries? What is the current relationship between the OECD Model and the UN Model? Does the frequent updating and development of the OECD Model suggest that by its vigour it will supplant the UN Model? Or is there a convergence between the respective positions: are earlier distinctions between developed and developing countries no longer relevant?

Some clues to the answers to these questions can be found in the recently published OECD Proceedings entitled Tax Treaties: Linkages between OECD Member Countries and Dynamic Non-Member Economies. ${ }^{1}$ The Proceedings represent the output of a workshop held in Oaxaca, Mexico in October 1995, and papers were presented under four subject headings:

- recent developments in international tax policies;

- recent changes in the OECD Model Convention and the impact on dynamic non-member economies;

- the application and interpretation of tax treaties; and

- exchange of information and mutual agreement procedures.

Discussion based on these papers then took place. The texts of the papers are stated as being published in their original form 'to promote faster distribution at a lower cost', so presumably the 12 -month period elapsing before publication has arisen from the need to prepare and agree the lucid and valuable Informal Summary of the Proceedings.

Firm indications emerge in the discussions that the supposed polarization between residence-based and source-based taxation is on further examination now seen more as a continuum, with countries taking varied positions between pure residence-based and pure source-based taxation but with none now at the extremes. It was not a question of the pre-eminence of source-based over residence-based taxation but rather a balance or 'sharing of revenue sacrifice', as one delegate expressed it. There was discussion of the extent to which source-based taxation, e.g. the imposition of withholding taxes on interest, simply increased the cost of finance to the borrower through an increase in the interest rate. The issue of the impact of new communication technologies on the viability of source-based taxation was outside the scope of the workshop.

There were some interesting comments on reasons for entering into treaties. On the one hand, Chile took the position that tax treaties had not been a priority in the past because it was achieving record levels of foreign direct investment without them. Chile had been concerned that entering into tax treaties might constrain its own ability to proceed with domestic tax reform. However, it now wished to encourage smaller investments, especially in the services sector, and felt that tax treaties might be the best way to deal with tax issues in these cases. A UK delegate felt that UK industry was happy to invest where there was no tax treaty but would not commit itself to very large investments in the absence of a treaty. Industry was mainly interested in the mutual agreement procedure and the non-discrimination article rather than the taxing rules, while the Inland Revenue was concerned with exchange of information. Japan stated that, in relation to the issue of tax incentives and investment, a poll of Japanese companies in early 1995 had revealed no priority on tax; companies simply welcomed the tax incentive after they had made the basic decision. One imagines here that the reference is to incentives given by the tax system and is not referring to investment subsidies and grants etc., which other experience suggests may play an important role, at least in the location of manufacturing or assembly plants.

There was an interesting discussion on the relationship between treaties and domestic law, an issue raised by a paper from Malaysia. This considered Malaysian domestic case law on the application of the royalty article in treaties where the definition of 'royalty' in the treaty differed from the definition in domestic law. There appeared to have been some misunderstanding of the position where such a definition was not synonymous. If the payment fell outside the treaty definition, did it escape taxation, assuming there was no permanent establishment? The decision in a recent 
case (which did not follow a previous decision) was that it did escape taxation. On the other hand, if the payment fell within the treaty definition but fell outside the domestic law definition did the treaty create a liability to tax? A decision in favour of the taxpayer on that point in another case was currently under appeal.

This issue of treaty provisions overriding domestic law so as to give relief is, of course, an important one. In many countries which are negotiating treaties for the first time there is not always a full understanding that the treaty is intended to have the effect of overriding domestic law. This may not be surprising because in such countries the domestic law may be fairly simple in its terms and by comparison the treaty is a highly sophisticated set of provisions; but there is little point in negotiating treaties if the effect is not understood, and adhered to, by both parties at the outset.

This discussion raised a further very interesting point regarding the relevance of the OECD Commentary in non-OECD states, In OECD states, the Commentary may be, and is, referred to under Art. 31 or 32 of the Vienna Convention, which being declaratory of existing international law, may be applicable even in countries which are not themselves a party to the Convention. There is debate as to the precise ground on which reference may be made in OECD states but there is a general consensus that in appropriate circumstances reference may indeed be made. What is the position then where the treaty partner is not an OECD member and therefore has taken no part (other than perhaps as an observer) in the formulation of the Commentary and has had no opportunity to offer observations or reservations? Some further study of this issue would be useful, because if in particular circumstances the Commentaries are referred to by one party but not by the other a potential source of friction or conflict of interpretation arises. Particular issues raised at the workshop by Korea, for example, concerning transfer pricing, agency and treatment of software could be much more easily understood and resolved by a study of the Commentaries.

The overall impression given by the workshop seemed to be one of a consensus on future cooperation. The OECD and UN Models could coexist in harmony and gradually integrate. The old archetypes are no longer relevant as differences become compressed by globalization. 